\title{
Bank Merger Policy and the New CRA Data
}

Anthony W. Cyrnak, of the Board's Division of Research and Statistics, prepared this article. Dennis W. Campbell provided research assistance.

One consequence of the current merger trend in the banking industry has been heightened interest in the analytical framework and data used by federal authorities to assess the competitive effects of bank mergers and bank holding company acquisitions (see box "Federal Antitrust Review of Bank Mergers"). Although the analytical methods used by the bank regulatory agencies and the Department of Justice are similar, some differences have emerged over time. Two issues related to these differences can now be examined using data collected for the first time as a result of 1995 changes in the regulations implementing the Community Reinvestment Act (CRA).

One of the issues is whether locally based commercial banks and savings institutions ("in-market" firms) face significant competition in small business lending from banks and savings institutions based outside local banking markets ("out-of-market" firms). This issue is important because, in the view of some banking industry observers, the presence and competitive influence of out-of-market firms in local banking markets warrant greater recognition by banking regulators and the Department of Justice. If the competitive role of out-of-market institutions were more fully recognized, they argue, more banking markets would be viewed as structurally competitive, and bank mergers within these markets would raise fewer antitrust concerns. ${ }^{1}$ The new CRA data can shed some light on this issue by providing information about the number of, and lending activity of, out-of-market small business lenders in urban and rural banking markets.

The other issue is whether levels of concentration within U.S. banking markets differ significantly when measured by small business loan originations rather than by bank deposits. Legal precedent and economic theory have traditionally supported the use of total bank deposits as the basis on which to calculate market concentration. This practice has been reexam-

1. To simplify discussion, the term mergers hereafter refers to both mergers of banks and acquisitions of banks by bank holding companies. ined in recent years, however, as industry observers have questioned whether competition in local banking markets might be better measured on the basis of some other variable, notably loans to small businesses. ${ }^{2}$ Competition in small business lending, some have argued, is more local than is competition for deposits and better reflects the competitive realities of local banking markets.

2. See, for example, "Are Deposits the Best Antitrust Measure?" Bank Mergers \& Acquisitions, vol. 12 (December 1997), pp. 1-4.

\section{Federal Antitrust Review of Bank Mergers}

All proposed mergers of insured banks and proposed acquisitions by bank holding companies must be approved by a federal banking regulator. The review of the proposal is conducted by the regulatory agency that would be the primary regulator for the surviving banking institution. If the resulting institution would be a national bank, the Office of the Comptroller of the Currency reviews the proposal. If it would be a state-chartered bank that is not a member of the Federal Reserve System, the Federal Deposit Insurance Corporation reviews the proposal. And if the proposal involves an acquisition by a bank holding company or the resulting bank would be a state-chartered member of the Federal Reserve System, the Federal Reserve is the reviewer. The Department of Justice, which has general enforcement authority under federal antitrust laws, reviews proposed mergers and acquisitions approved by the banking regulators.

Proposals for banking consolidations are reviewed under two primary federal statutes, the Bank Merger Act of 1960 (as amended in 1966) and the Bank Holding Company Act of 1956 (as amended in 1970). The legal standards applied by the banking regulators under these statutes correspond to the standards set forth in the Sherman Antitrust Act of 1890 and the Clayton Act of 1914. Specifically, no bank merger or bank holding company acquisition may be approved if the effect of the merger or acquisition would be to create a monopoly (Sherman Act) or may substantially lessen competition or tend to create a monopoly in a particular market (Clayton Act). Importantly, the Clayton Act does not define the term "substantially." Court decisions, as well as the legislative history of this act, however, make it clear that the term must be examined in the context of each industry. 


\section{Concentration, the HHI, and the Department of Justice Merger Guidelines}

Market concentration is an important factor in the competitive analyses of mergers and acquisitions conducted by federal bank regulatory agencies and the Department of Justice. Both theoretical models and empirical studies suggest that higher levels of market concentration are generally associated with less competition, higher prices, and greater profitability. These relationships are consistent with the "structure-conduct-performance" paradigm, which suggests that there is a causal relationship between the structure of a market (the number and size distribution of firms within a market and factors affecting the ability of new firms to enter that market), the behavior of firms within that market (competition, collusion, or other competitive strategies), and the performance of firms in that market (typically, profits, prices, or firm growth).

The Department of Justice has for many years published formal guidelines that identify structural changes resulting from mergers that are likely to cause the department to challenge a merger. Since 1982, the department has based its merger guidelines on the Herfindahl-Hirschman index of concentration (HHI). This measure, which is also used by the bank regulatory agencies, is calculated by squaring the market share of each firm competing in a defined geographic banking market and then summing the squares. The $\mathrm{HHI}$ can range from zero in a market having an infinite number of firms to 10,000 in a market having just one firm (with a 100 percent market share). ${ }^{1}$

The HHI is a static measure and, therefore, gauges market concentration at a single point in time. Algebraically, it can be depicted as

$$
\mathrm{HHI}=\sum_{i=1}^{n}\left(M S_{i}\right)^{2}
$$

where $M S$ is the market share of the $i$ th firm and $n$ is the number of firms in the market.

The HHI is a particularly useful tool for bank merger analysis because it accounts for the presence of every competitor in a market and provides a measure of the

1. A more complete discussion of the HHI is presented in Stephen A. Rhoades, "The Herfindahl-Hirschman Index," Federal Reserve Bulletin, vol. 79 (March 1993), pp.188-89. structural effect of a merger of any firms in a market. In addition, the squaring of market shares gives greater weight to firms that have large market shares. This weighting of the largest competitors in a market is consistent with economic theories that predict weak competition in markets in which a few competitors hold a large combined market share.

A merger of two banking competitors will increase the $\mathrm{HHI}$ in their shared market. (Mathematically, the increase is equal to the product of the two firms' market shares times two.) The amount of the increase and the level to which the HHI would rise after the merger are key elements in the structural analysis of bank mergers. In the Department of Justice's guidelines, markets with an HHI of less than 1000 are considered "unconcentrated"; those with an HHI of 1000 to 1800 are "moderately concentrated"; and those with an HHI greater than 1800 are "highly concentrated."

The department's merger guidelines for nonbanking industries generally indicate that a merger that increases the HHI 50 points or less in a highly concentrated market is unlikely to have adverse competitive effects and ordinarily would not be challenged on antitrust grounds. The department's guidelines for the banking industry are more lenient, largely in recognition of the widespread presence of nonbanking providers of financial services. In particular, in 1985, the department stated that it would not ordinarily challenge a proposed bank merger unless the rise in the HHI would be more than 200 points in a highly concentrated market. This practice was subsequently adopted by the Federal Reserve System as part of its Rules Regarding Delegation of Authority, an administrative procedure that allows certain mergers to be approved directly by the Reserve Banks. (Proposed bank mergers that raise substantive issues must normally be acted upon by the Board of Governors following a formal review and voting process.)

Although these structural guidelines constitute a critical screening device for the Department of Justice and the banking regulators, the analysis of other economic factors is also an integral part of the assessment of the competitive effects of consolidation. These factors can include, for example, market economic conditions, trends in concentration, and the competitiveness of other banking and thrift institutions.
The measurement of market concentration plays a key role in the competitive analysis of proposed bank mergers (see box "Concentration, the HHI, and the Department of Justice Merger Guidelines"). Generally, banking regulators and the Department of Justice intensively review any proposed merger that would add significantly to and result in a high degree of market concentration. Importantly, concentration indexes can be calculated using various types of data depending on the type of product for which compe- tition is being analyzed. The use of different data, moreover, is likely to result in different calculated levels of concentration. Thus, the choice of a product market and the type of data used to measure concentration could influence the regulatory outcome of a merger proposal.

The new CRA data make it possible to consider this second issue by examining the level of concentration within U.S. banking markets using a base other than bank deposits, namely small business loan origi- 
nations. The results of this examination may suggest whether, on average, antitrust standards are likely to be more or less difficult to meet when concentration measures are based on small business loans rather than on deposits.

\section{OVERVIEW OF BANKING ANTITRUST POLICY}

Antitrust policy in the United States generally recognizes that competition results in lower prices and better service for consumers. Thus, a primary goal of banking antitrust policy is to prevent the creation of, or an increase in, market power such that a firm could impose above-competitive prices and earn excess profits at the expense of consumers.

Mergers in the banking industry are subject to the same antitrust standards as are mergers in other industries. This principle was made clear by the U.S. Supreme Court in its 1963 decision involving the proposed merger of two competing Philadelphia banking institutions. ${ }^{3}$ In that case (Philadelphia National Bank) the Court made three findings that have become fundamental tenets of banking antitrust policy in the United States. First, antitrust laws apply to banking mergers, and the legal standards for judging mergers in the banking industry are the same as those embodied in the Sherman Antitrust Act of 1890 and the Clayton Act of 1914. Second, commercial banking is a distinct line of commerce in which banks provide a unique "cluster" of products and services not provided by any other type of financial institution. ${ }^{4}$ Third, commercial banks compete in local markets, primarily because of their need to provide convenient service to their customers.

In reaching its decision, the Supreme Court validated the "structural" approach to analyzing the competitive effects of bank mergers. In this approach, the likely competitive effect of a proposed bank merger is presumed to be indicated by the merger's effect on such structural variables as market concentration, market shares, and the number of competitors in the banking market. ${ }^{5}$ The structural approach requires that both a product market and a geographic

3. United States v. Philadelphia National Bank, 374 U.S. 321 (1963).

4. The Court noted that, among other products and services, demand deposits, trust administration, and various types of credit such as commercial lending are uniquely supplied by commercial banks and constitute key elements of the banking cluster.

5. Other approaches to merger analysis may emphasize the likely effects on the behavior of the merger participants and may examine business strategy, activity, and pricing as guides to assessing competition. market be defined in order to determine whether the merging banks provide substitutable products to essentially the same group of customers. If they do, it can be assumed that they operate within the same product and geographic markets and that their merger would lessen competition.

For such mergers, regulators must then determine whether the loss of competition may be substantial. Generally, the expected loss of competition is assumed to be serious if the market share of the surviving bank would increase significantly, to a high level, and if the merger would increase market concentration substantially, to a high level. In such a case, banking regulators would be unlikely to approve the merger unless significant mitigating factors were present. Even if such a merger were approved by a bank regulatory agency, it could be challenged by the Department of Justice. To minimize regulatory uncertainty and to provide a more consistent interpretation of merger-induced structural changes within banking markets, the Department of Justice has for many years published formal guidelines that indicate which mergers are likely to exceed its antitrust standards. To a large extent, the banking regulators have adopted these standards as part of their merger analyses.

A significant aspect of Philadelphia National Bank was that it established legal precedents for defining a single product market (the "cluster" of products and services) and for defining geographic banking markets as being local in extent. Since 1963, these definitions have been used widely and have been supported by both agency and court decisions. ${ }^{6}$ However, the definitions have been controversial, particularly in recent years as the number of nonbank firms that provide bank-like financial products on a nationwide basis has increased. Some observers believe that the relevant product market in banking is no longer a single cluster of products and services provided only by commercial banks. Nor do they believe that geographic banking markets are local in extent. Rather, they argue, banks provide multiple and largely discrete financial products in broad geographic markets that in some instances are national in extent. Not surprisingly, some of these observers believe that a banking antitrust policy based on the cluster product market and local geographic markets is no longer relevant and does not reflect competitive realities. Above all, they argue, current policy may be unduly restrictive.

6. See, for example, United States v. Marine Bancorporation, 418 U.S. 602 (1974); and United States v. Central State Bank, 621 F. Supp. 1276, 1292 (W.D. Mich., 1985), Aff'd 817 F.2d, 22 (6th Cir., 1987). 


\section{DIFFERENCES IN MERGER ANALYSIS}

Federal banking regulators and the Department of Justice commonly take the structural approach in assessing the competitive effects of proposed bank mergers, and their methods of analysis are generally similar. Some differences exist, however. One important example is that the Federal Reserve continues to define the product market as the "cluster" of products and services described in Philadelphia National Bank, whereas the Department of Justice typically disaggregates the product market into two or more customer classes-usually banking services for consumers and banking services for small businesses (mainly lending).

The separation of customer classes typically results in some differences in the way proposed mergers are analyzed. Among the aspects of merger analysis that may be affected are the definition of geographic markets, the competitive role accorded thrift institutions and nonbanking firms, and divestiture policy. Perhaps most important, the separation of customer classes affects the choice of data with which to calculate concentration, a key variable in bank merger analysis. In particular, whereas the Federal Reserve relies on commercial bank and thrift deposits as the measure of the cluster of products and services, the Justice Department may use business lending and services, or it may use commercial bank deposits only.

These differences in analytical methods stem largely from differing assumptions about bank behavior, consumer preferences, and the competitiveness of banking markets. The use of deposits as a proxy for a bank's ability to provide the cluster of products and services to customers embodies two key assumptions. One assumption is that the product mix of a bank is a matter of managerial prerogative, and that this mix, which includes business loans, can be changed easily. The other is that all banks within a geographic banking market influence the pricing of products, even if they do not offer an identical range of products and services.

The practice of disaggregating the product market rests largely on the assumption that retail banking services and business banking services (and possibly others) are distinct products that face different supply and demand conditions. For example, competition to provide the financial services used by small businesses (primarily small business lending) is often regarded as weaker and more locally limited than competition to provide the retail services used by households. Thus, mergers that affect competition within the business customer class may require closer antitrust scrutiny.

\section{THE CRA DATA}

The data on small business loans used in this analysis came primarily from depository institutions reporting under the Community Reinvestment Actindependent commercial banks and savings institutions (savings banks and savings and loan associations) with total assets of $\$ 250$ million or more and institutions of any size if owned by a holding company with total assets of $\$ 1$ billion or more. ${ }^{7}$ The CRA data cover the 1996 originations of small business loans by 1,871 institutions-1,460 commercial banks and 411 savings institutions. ${ }^{8}$ These institutions ("CRA reporters"), which constitute 16 percent of all U.S. commercial banks and savings institutions, reported having originated 2.4 million small business loans in 1996 totaling \$145 billion. These loans accounted for about two-thirds of the total dollar volume of small business loans made by all depository institutions in the United States in that year.

Included among the CRA reporters are banks whose primary activity is credit card lending. Twelve credit card banks reported having originated credit card small business loans in $1996 .{ }^{9}$ These institutions, though small in number, can have a large effect on analytical results, particularly in urban markets. Overall, they accounted for 30 percent of all small business loans reported under the CRA, though only 2.9 percent of the dollar volume of such loans.

The CRA loan data are geocoded, that is, reported by geographic location of the borrower (census tract or block number area), making it possible to aggre-

7. Some loan data came from other sources; see footnote 11.

For additional information on the new CRA data, see Raphael W. Bostic and Glenn B. Canner, "New Information on Lending to Small Businesses and Small Farms: The 1996 CRA Data," Federal Reserve Bulletin, vol. 84 (January 1998), pp. 1-21.

8. Small business loans are defined as commercial and industrial loans having an original amount of $\$ 1$ million or less. This definition of a small business loan for CRA purposes is the same as that used for the Report of Condition and Income (Call Report), the quarterly report submitted by banks to their primary regulator and the FDIC, and for the Thrift Financial Report, the quarterly report submitted by savings and loan associations to the Office of Thrift Supervision. By focusing on loan amount, the term refers to a small loan made to a business of any size; such a loan may or may not be a loan to a small business. See box "When Is a Small Business Loan Not a Loan to a Small Business?"

9. The CRA regulations direct institutions that issue credit cards to the employees of small businesses to report all of the credit card lines opened on a particular day as a single business loan, with the "amount of the loan" equivalent to the sum of the available credit lines of those credit card accounts opened on that day. 


\section{When Is a Small Business Loan Not a Loan to a Small Business?}

"Small business loans" are often not loans to small businesses but, rather, small loans to businesses that are quite large. This distinction can be important to policymakers seeking to preserve or create credit opportunities for small firms.

For this article, small business loans are defined as they are for reporting by lenders under the Community Reinvestment Act (CRA reporters)-commercial and industrial loans of $\$ 1$ million or less extended to businesses of any size. However, because CRA reporters must indicate separately the number and dollar volume of small business loans made to firms having annual revenues of $\$ 1$ million or less, the data can be used to determine the proportion of small business loans made to small businesses (when a small business is defined as one having annual revenues of $\$ 1$ million or less). ${ }^{1}$

In urban markets, 54.4 percent of small business loans originated in 1996 by CRA reporters were made to "small" firms. In-market CRA reporters made 60 percent of their small business loans to small firms, compared with only 47 percent for out-of-market CRA lenders. Thus, it appears that out-of-market lenders make a greater proportion of their small business loans to "large" firms (those having annual revenues of more than $\$ 1$ million). One possible explanation for this finding is that firms eventually outgrow their local banking institutions and need to go out of market to obtain financing, particularly when they are in small markets. For CRA reporters as a group, the proportion of small business loans extended to firms having annual revenues of $\$ 1$ million or less increases as market population decreases. This inverse relationship probably reflects the relative scarcity of large businesses in smaller markets.

Similar results were found for rural markets; however, the proportion of small business loans made to small firms across rural markets of all sizes was somewhat higher. In rural markets, CRA reporters made 68 percent of their small business loans to firms having annual revenues of $\$ 1$ million or less. As with urban markets, in-market reporters made a higher proportion of their small business loans to smaller firms (78 percent) than did out-of-market CRA reporters (45 percent). Also as with urban markets, the data generally show an inverse relationship between market population and the proportion of small business loans extended to small firms.

1. There is no commonly accepted criterion defining a "small business." The 1993 National Survey of Small Business Finances (sponsored by the Federal Reserve Board and the U.S. Small Business Administration), which defines small businesses as those having fewer than 500 employees, notes that about 84 percent of all small businesses have annual revenues of less than $\$ 1$ million. For a discussion of that survey, see Rebel A Cole, John D. Wolken, and R. Louise Woodburn, "Bank and Nonbank Competition for Small Business Credit: Evidence from the 1987 and 1993 National Surveys of Small Business Finances," Federal Reserve Bulletin, vol. 82 (November 1996), pp. 983-95. gate lending data for in-market and out-of-market CRA reporters by geographic market. ${ }^{10}$

\section{SMALL BUSINESS LENDING ACTIVITY}

The CRA data for urban and rural markets were analyzed separately because such markets generally have different economic characteristics, structures, and degrees of competition.

\section{Urban Markets}

Much of the merger activity in recent years has been in large metropolitan banking markets. Proponents of mergers often argue that out-of-market lenders are an important source of small business credit in these large markets but that their influence on competition is largely overlooked. To assess the competitive importance of out-of-market lenders in these markets, the data were aggregated across metropolitan statistical areas (MSAs) - the 313 urban population centers in the United States that are frequently used in economic research and merger analysis as approximations for urban geographic banking markets.

\section{Presence of Small Business CRA Lenders}

Every MSA has at least one in-market institution reporting small business lending (CRA reporter), and these reporters constitute a sizable proportion of the total number of institutions within these markets (table 1). ${ }^{11}$ Perhaps more important, the average number of out-of-market reporters in MSAs of all sizes is quite large relative to the number of all in-market institutions. In fact, for all but the largest MSA size category, the number of out-of-market CRA reporters exceeds the number of in-market firms. This is a potentially important finding because it supports the claims of some merger advocates that, on average, a relatively large number of out-of-market banks and

10. In addition, CRA reporters must indicate the number and dollar volume of their small business loans by size class $(\$ 100,000$ or less, $\$ 100,001-\$ 250,000$, or $\$ 250,001-\$ 1$ million) and the number and dollar volume of loans to firms having annual revenues of $\$ 1$ million or less.

11. Data for institutions not reporting small business loans under the Community Reinvestment Act ("nonreporters") were taken from or derived from the Call Report, the Thrift Financial Report, and the Summary of Deposits report (which is submitted both by banks and by savings and loan associations to their primary regulator and the FDIC). Population data used to categorize both urban and rural markets by size were derived from 1994 regional economic accounts, Bureau of Economic Analysis, U.S. Department of Commerce. 
1. Average number of selected types of lending institutions per urban market, by type of institution and size of market, 1996

\begin{tabular}{|c|c|c|c|c|c|c|}
\hline \multirow{2}{*}{ Type of lending institution } & \multicolumn{5}{|c|}{ Market population (thousands) } & \multirow{2}{*}{$\begin{array}{l}\text { All urban } \\
\text { markets }\end{array}$} \\
\hline & $\begin{array}{l}\text { More than } \\
5,000\end{array}$ & $1,000-5,000$ & $500-999$ & $250-499$ & $\begin{array}{l}\text { Less than } \\
250\end{array}$ & \\
\hline All in-market institutions & 203 & 60 & 28 & 19 & 13 & 27 \\
\hline In-market CRA reporters .... & 58 & 18 & 11 & 9 & 6 & 10 \\
\hline Out-of-market CRA reporters & 105 & 65 & 39 & 27 & 19 & 32 \\
\hline Excluding credit card banks .. & 103 & 63 & 37 & 25 & 17 & 30 \\
\hline \multicolumn{7}{|l|}{ Мемо } \\
\hline $\begin{array}{l}\text { Ratio of in-market CRA reporters to all } \\
\text { in-market institutions } \ldots \ldots \ldots \ldots \ldots \ldots\end{array}$ & .29 & .30 & .39 & .47 & .46 & .37 \\
\hline $\begin{array}{l}\text { Ratio of out-of-market CRA reporters to all } \\
\text { in-market institutions }\end{array}$ & .52 & 1.08 & 1.39 & 1.42 & 1.46 & 1.19 \\
\hline $\begin{array}{l}\text { Ratio of out-of-market CRA reporters to all } \\
\text { institutions }{ }^{1}\end{array}$ & .34 & .52 & 58 & 59 & 59 & 54 \\
\hline Number of markets $\ldots \ldots \ldots \ldots \ldots \ldots \ldots \ldots$ & 4 & 51 & 42 & 70 & 146 & 313 \\
\hline
\end{tabular}

NotE. Urban markets are metropolitan statistical areas as defined by the U.S. Department of Commerce. All markets have at least one in-market CRA reporter.
1. Denominator is all in-market institutions plus out-of-market CRA reporters. savings institutions make small business loans in urban markets.

Of course, the mere presence of out-of-market small business lenders-even in large relative numbers-does not necessarily demonstrate that such firms are an important competitive force within urban markets. They may have a relatively small presence in terms of number or dollar volume of small business loans originated.

\section{Number of Loans}

Although in-market CRA reporters typically constitute less than half of all in-market firms (table 1, first memo item), these reporters, in each MSA size category, account for about two-thirds of the estimated number of small business loans made by all in-market firms (table 2). ${ }^{12}$ The dominance of in-market CRA reporters is not particularly surprising: Because of the asset-size criteria for reporting under the CRA, reporters tend to be the larger firms within banking markets - and in many markets these institutions are the most active small business lenders.

A more important observation is that the average number of small business loans originated by outof-market reporters is, for each MSA size category, considerably smaller than the average number of small business loans originated by in-market firms. This result is noteworthy because out-of-market lenders outnumber in-market lenders in all but one MSA size category (table 1). Thus, out-of-market CRA

12. Small business loan originations by each in-market nonreporter were estimated by (1) multiplying the ratio of its small business loans outstanding to its deposits by its local, in-market deposits and then (2) multiplying that product by 60 percent, the approximate ratio of small business loan originations to small business loans outstanding for all CRA reporters. lenders account for a considerably smaller number of loans than might be suggested by their presence relative to in-market firms.

Interestingly, not only is the share of small business loans originated by out-of-market reporters considerably less than that originated by in-market firms (in terms of number made), but this market share decreases steadily as the population of the MSA decreases. The data show, therefore, that as urban markets decrease in population, so does the importance of out-of-market lenders, as measured by their share of the small business loans originated. As will be seen later, this relationship also exists for rural markets of different sizes.

The direct relationship between market population and the market share of out-of-market firms has several possible explanations. One is that out-of-market lenders simply view smaller markets as being potentially less profitable and, therefore, expend relatively less effort on developing a lending business in such markets. Another is that businesses in small markets have strong and long-standing ties to local lenders that are not easily competed away by out-of-market firms. A number of observers have noted that the credit conditions faced by a small business are likely to be influenced by the nature of the borrower-lender relationship. In particular, when credit relationships are of long standing, lenders are likely to have better information about borrowers, and this knowledge may result in more favorable terms on business loans. Thus, a small business borrower probably has an incentive (in addition to convenience) to develop and maintain a close relationship with a lender that is based in its banking market. ${ }^{13}$

13. This issue was recently discussed in Katherine Samolyk, "Small Business Credit Markets: Why Do We Know So Little about Them?" FDIC Banking Review, vol. 10, no. 2 (1997), pp. 14-32. 
2. Average number of small business loans originated per urban market, by type of lending institution and size of market, 1996

\begin{tabular}{|c|c|c|c|c|c|c|}
\hline \multirow{2}{*}{ Type of lending institution } & \multicolumn{5}{|c|}{ Market population (thousands) } & \multirow{2}{*}{$\begin{array}{l}\text { All urban } \\
\text { markets }\end{array}$} \\
\hline & $\begin{array}{l}\text { More than } \\
5,000\end{array}$ & $1,000-5,000$ & $500-999$ & $250-499$ & $\begin{array}{l}\text { Less than } \\
\quad 250\end{array}$ & \\
\hline All in-market institutions ${ }^{1}$ & 44,291 & 14,409 & 5,601 & 3,338 & 1,775 & 5,239 \\
\hline In-market CRA reporters $\ldots$. & 29,443 & 9,646 & 4,106 & 2,340 & 1,140 & 3,554 \\
\hline Out-of-market CRA reporters ... & 29,579 & 7,370 & 2,297 & 1,039 & 466 & 2,337 \\
\hline Excluding credit card banks ... & 4,728 & 1,321 & 504 & 244 & 121 & 454 \\
\hline \multicolumn{7}{|l|}{ МЕмо } \\
\hline $\begin{array}{l}\text { Ratio of loans by in-market CRA reporters } \\
\text { to loans by all in-market institutions } \ldots . . .\end{array}$ & .66 & .67 & .73 & .70 & .64 & .68 \\
\hline Ratio of loans by out-of-market CRA reporters & .00 & & & & & \\
\hline to loans by all in-market institutions..... & .67 & .51 & .41 & .31 & .26 & .45 \\
\hline Ratio of loans by out-of-market CRA reporters & 40 & & & 24 & & 31 \\
\hline Excluding credit card banks $\ldots \ldots \ldots \ldots \ldots$ & $\begin{array}{l}.40 \\
.10\end{array}$ & $\begin{array}{l}.34 \\
.08\end{array}$ & $\begin{array}{l}.29 \\
.08\end{array}$ & $\begin{array}{l}.24 \\
.07\end{array}$ & $\begin{array}{l}.21 \\
.06\end{array}$ & $\begin{array}{l}.31 \\
.08\end{array}$ \\
\hline
\end{tabular}

When the small business loan originations of credit card banks are deducted from the out-of-market totals, the number of loans made by out-of-market CRA lenders falls sharply (table 2). For example, in the largest MSAs, the average number of small business loans by out-of-market firms drops from 29,579 to only 4,728. All other MSA size categories exhibit similar proportional declines.

The effect of these declines, not surprisingly, is to substantially reduce the market shares held by out-ofmarket CRA reporters. For example, for the largest MSAs, the share of small business loans originated by out-of-market firms declines from 40 percent to just 10 percent when credit card banks are excluded. Similar sharp declines occur for all other MSA size categories. For all MSAs combined, the share declines from 31 percent to just 8 percent.

The competitive significance of credit card banks is not clear. The new CRA data do indicate that they account, on average, for a significant proportion of small business loans within urban markets. However, whether a credit card small business loan is the functional and competitive equivalent of other small business loans is arguable. Certainly, national surveys of small business lending have demonstrated that many small businesses regularly use credit cards as a source of credit. However, several factors suggest that credit card loans may differ from other small business loans. For example, the average credit card loan is considerably smaller, and the credit standards associated with credit card loans may not be as stringent as those for conventional small business loans.

\section{Dollar Volume of Loans}

The average dollar volume of small business loan originations within MSAs declines as MSA population decreases (table 3). This pattern reflects the lower absolute level of aggregate loan demand typically associated with smaller banking markets.

A large proportion of the dollar volume of small business lending by in-market firms is accounted for by in-market CRA reporters (first memo item). This finding is noteworthy because it suggests that the small business lending activity of all banks and savings associations based within urban markets can be approximated rather closely by using only data from CRA reporters. For example, for all MSAs combined, in-market CRA reporters accounted for 88 percent of the average dollar volume of all small business loans originated by in-market lenders (though they originated only 68 percent of the number of such loans across all MSAs).

Perhaps the most important observation from the data in table 3 is that out-of-market CRA reporters account, on average, for a relatively small proportion of the dollar volume of small business lending in urban markets (third memo item). This finding is somewhat surprising, given that out-of-market CRA reporters generally outnumber in-market firms in urban markets and account for a sizable proportion of small business loans in these markets by number.

Across all MSAs, the average volume of small business lending by all in-market firms in 1996 was \$388.5 million, compared with only \$32.8 million for out-of-market CRA reporters. Thus, out-of-market CRA reporters accounted, on average, for only 8 percent of the average dollar volume of small business loan originations across all MSAs (third memo item). This small market share in terms of dollar volume contrasts sharply with the share held by out-ofmarket CRA reporters in terms of number of loans (31 percent, table 2) and their relative presence in urban markets (54 percent of lenders are out-ofmarket CRA reporters, table 1). Similarly small dollar shares are found for each MSA size category. 
3. Average dollar volume of small business loans originated per urban market, by type of lending institution and size of market, 1996

Millions of dollars

\begin{tabular}{|c|c|c|c|c|c|c|}
\hline \multirow{2}{*}{ Type of lending institution } & \multicolumn{5}{|c|}{ Market population (thousands) } & \multirow{2}{*}{$\begin{array}{l}\text { All urban } \\
\text { markets }\end{array}$} \\
\hline & $\begin{array}{l}\text { More than } \\
5,000\end{array}$ & $1,000-5,000$ & $500-999$ & $250-499$ & $\begin{array}{l}\text { Less than } \\
\quad 250\end{array}$ & \\
\hline All in-market institutions ${ }^{1}$ & $3,973.8$ & $1,119.5$ & 415.7 & 224.2 & 105.6 & 388.5 \\
\hline In-market CRA reporters $\ldots$. & $3,424.2$ & 985.1 & 378.0 & 201.4 & 90.6 & 342.4 \\
\hline Out-of-market CRA reporters . & 351.1 & 97.3 & 35.3 & 16.5 & 8.6 & 32.8 \\
\hline Excluding credit card banks ... & 214.9 & 65.9 & 26.1 & 12.5 & 7.0 & 23.0 \\
\hline \multicolumn{7}{|l|}{ МЕмо } \\
\hline $\begin{array}{l}\text { Ratio of volume by in-market CRA reporters } \\
\text { to volume by all in-market institutions } \ldots \\
\text { Ratio of volume by out-of-market CRA }\end{array}$ & .86 & .88 & .91 & .90 & .86 & .88 \\
\hline $\begin{array}{l}\text { reporters to volume by all in-market } \\
\text { institutions } \ldots \ldots \ldots \ldots \ldots \ldots \ldots \ldots\end{array}$ & .09 & .09 & .08 & .07 & .08 & .08 \\
\hline Ratio of volume by out-of-market CRA & & & & & & \\
\hline reporters to volume by all institutions ${ }^{2}$ & .08 & .08 & .08 & .07 & .08 & .08 \\
\hline Excluding credit card banks ............ & .05 & .06 & .06 & .05 & .06 & .06 \\
\hline
\end{tabular}

NotE. See general note to table 1.

1. Covers loans reported by CRA reporters and estimated loans by

2. Denominator is volume of loans made by all in-market institutions plus nonreporters.

The results for urban markets appear to provide important evidence regarding the competitive role of out-of-market firms in such markets. Specifically, the 1996 CRA data show that out-of-market lenders are, on average, both numerous and active small business lenders compared with in-market firms. However, these lenders account, on average, for only a small proportion (typically 7 percent or 8 percent) of the dollar volume of small business lending in MSAs of various sizes. Moreover, when credit card banks are excluded, the share of originations by out-of-market CRA reporters, in terms of dollar volume, is even less (typically 5 percent or 6 percent).

\section{Rural Markets}

Proposals for bank mergers in rural markets often raise particularly serious antitrust issues. Typically, rural markets are more highly concentrated than urban markets and have relatively few competitors. Many rural markets are not attractive for new entry because of their small population and modest economic prospects. Thus, any adverse competitive effects resulting from a bank merger are likely to persist. As in urban markets, however, parties to proposed bank mergers frequently argue that competition in rural markets is understated because the regulatory agencies and the Department of Justice in their analyses do not take into account the competitive influence of out-of-market banks and savings institutions.

The data considered here provide some evidence relevant to this argument. In general, they are consistent with the data for urban markets in that out- of-market CRA reporters, on average, outnumber in-market firms. In rural markets, however, out-ofmarket CRA reporters account for a smaller proportion of small business loan originations by number of loans, and a somewhat higher proportion by dollar volume of loans. The higher proportion of dollar lending suggests that out-of-market lenders are a relatively more important source of competition for small business lending in rural markets than in urban markets.

\section{Presence of Small Business CRA Lenders}

The majority of rural markets (non-MSA counties that have at least one banking or savings institution) are quite small and have a population of less than 25,000 (table 4). A large proportion of these markets (68 percent) have at least one in-market CRA reporter.

Rural markets, on average, have six in-market banking and savings institutions, and two of the six are CRA reporters. Not surprisingly, the number of both in-market institutions and in-market CRA reporters declines with market population.

The average number of out-of-market CRA reporters in rural markets (as in urban markets) is larger than the average number of in-market institutions; for example, for all rural markets, the average ratio of out-of-market CRA reporters to all in-market firms is 1.67. Moreover, the ratio of out-of-market reporters to in-market firms is inversely related to market size. This relationship, which also characterizes urban markets, indicates that out-of-market competitors have a relatively greater presence in smaller markets than in larger markets. 
4. Average number of selected types of lending institutions per rural market, by type of institution and size of market, 1996

\begin{tabular}{|c|c|c|c|c|c|}
\hline \multirow{2}{*}{ Type of lending institution } & \multicolumn{4}{|c|}{ Market population (thousands) } & \multirow{2}{*}{$\begin{array}{l}\text { All rural } \\
\text { markets }\end{array}$} \\
\hline & More than 100 & $50-100$ & $25-49$ & Less than 25 & \\
\hline In-market institutions $\ldots \ldots \ldots \ldots \ldots \ldots$ & 12 & 9 & 7 & 4 & 6 \\
\hline In-market CRA reporters $\ldots \ldots \ldots \ldots \ldots$ & 6 & 4 & 3 & 2 & 2 \\
\hline Out-of-market CRA reporters $\ldots \ldots \ldots \ldots$ & 18 & 14 & 12 & 8 & 10 \\
\hline Excluding credit card banks . & 16 & 12 & 10 & 7 & 8 \\
\hline \multicolumn{6}{|l|}{ Мемо } \\
\hline $\begin{array}{l}\text { Ratio of in-market CRA reporters to all } \\
\text { in-market institutions } \ldots \ldots \ldots \ldots \ldots \ldots\end{array}$ & .50 & .44 & .43 & .50 & .33 \\
\hline $\begin{array}{l}\text { Ratio of out-of-market CRA reporters to all } \\
\text { in-market institutions } \ldots \ldots \ldots \ldots \ldots \ldots \ldots\end{array}$ & \multirow[t]{2}{*}{1.50} & 1.56 & 1.71 & 2.00 & 1.67 \\
\hline $\begin{array}{l}\text { Ratio of out-of-market CRA reporters to all } \\
\text { institutions }{ }^{1} \ldots \ldots \ldots \ldots \ldots \ldots \ldots \ldots\end{array}$ & & .61 & .63 & .67 & .63 \\
\hline Number of markets $\ldots \ldots \ldots \ldots \ldots \ldots \ldots \ldots$ & 26 & 199 & 485 & 1,561 & 2,271 \\
\hline $\begin{array}{l}\text { Number of markets with an in-market CRA } \\
\text { reporter } \ldots \ldots \ldots \ldots \ldots \ldots \ldots \ldots \ldots \ldots \ldots \ldots\end{array}$ & 26 & 195 & 450 & 881 & 1,552 \\
\hline
\end{tabular}

\section{Number of Loans}

The relative number of small business loans made by in-market and out-of-market lenders is a potentially important gauge for determining the level of competition in a banking market. For rural markets, as for urban markets, the number of small business loans originated in 1996 diminished with market population (table 5). This pattern most likely reflects the lower loan demand associated with smaller markets and fewer business borrowers of all sizes.

The proportion of in-market loans originated by in-market CRA lenders declines as market population decreases (first memo item). For example, the proportion of in-market loans made by in-market CRA lenders is 0.65 for the largest rural markets, compared with 0.44 for the smallest rural markets. For all rural markets, the ratio is 0.51 , somewhat smaller than the 0.68 ratio for urban markets (table 2).
The share of small business loans made by out-ofmarket CRA reporters generally declines as market population decreases (table 5 , third memo item). This finding is somewhat surprising, given that the number of such firms relative to the total number of in-market institutions increases as market population decreases (table 4, second memo item). This relationship, which also exists for urban markets, may reflect a preference by small firms in small, more concentrated markets to borrow from local institutions.

\section{Dollar Volume of Loans}

As in urban markets, in-market CRA reporters account for most of the dollar volume of small business lending by in-market institutions in rural markets, averaging 74 percent across all rural markets (table 6). However, the relative volume of lending by

5. Average number of small business loans originated per rural market, by type of lending institution and size of market, 1996

\begin{tabular}{|c|c|c|c|c|c|}
\hline \multirow{2}{*}{ Type of lending institution } & \multicolumn{4}{|c|}{ Market population (thousands) } & \multirow{2}{*}{$\begin{array}{l}\text { All rural } \\
\text { markets }\end{array}$} \\
\hline & More than 100 & $50-100$ & $25-49$ & Less than 25 & \\
\hline All in-market institutions ${ }^{1} \ldots \ldots \ldots$ & 961 & 870 & 507 & 213 & 398 \\
\hline In-market CRA reporters $\ldots \ldots \ldots \ldots$ & 625 & 514 & 236 & 94 & 201 \\
\hline Out-of-market CRA reporters ... & 366 & 185 & 92 & 40 & 80 \\
\hline Excluding credit card banks & 106 & 64 & 44 & 22 & 36 \\
\hline \multicolumn{6}{|l|}{ МЕмо } \\
\hline $\begin{array}{l}\text { Ratio of loans by in-market CRA reporters } \\
\text { to loans by all in-market institutions } \ldots \ldots\end{array}$ & 65 & .59 & .47 & .44 & .51 \\
\hline Ratio of loans by out-of-market CRA reporters & .03 & .59 & .41 & .44 & .51 \\
\hline to loans by all in-market institutions ...... & .38 & .21 & .18 & .19 & .20 \\
\hline \multicolumn{6}{|l|}{ Ratio of loans by out-of-market CRA reporters } \\
\hline to loans by all institutions ${ }^{2} \ldots \ldots \ldots \ldots \ldots$ & .28 & .18 & .15 & .16 & .17 \\
\hline Excluding credit card banks $\ldots \ldots \ldots \ldots \ldots \ldots$ & .10 & .07 & .08 & .09 & .08 \\
\hline
\end{tabular}


6. Average dollar volume of small business loans originated per rural market, by type of lending institution and size of market, 1996

Millions of dollars

\begin{tabular}{|c|c|c|c|c|c|}
\hline \multirow{2}{*}{ Type of lending institution } & \multicolumn{4}{|c|}{ Market population (thousands) } & \multirow{2}{*}{$\begin{array}{l}\text { All rural } \\
\text { markets }\end{array}$} \\
\hline & More than 100 & $50-100$ & $25-49$ & Less than 25 & \\
\hline All in-market institutions ${ }^{1}$ & 53.8 & 43.7 & 18.5 & 6.3 & 15.6 \\
\hline In-market CRA reporters $\ldots .$. & 46.8 & 35.5 & 13.0 & 4.0 & 11.5 \\
\hline Out-of-market CRA reporters & 7.7 & 4.9 & 3.1 & 1.5 & 2.5 \\
\hline Excluding credit card banks & 6.3 & 4.3 & 2.9 & 1.4 & 2.3 \\
\hline \multicolumn{6}{|l|}{ Мемо } \\
\hline $\begin{array}{l}\text { Ratio of volume by in-market CRA reporters } \\
\text { to volume by all in-market institutions .. } \\
\text { Ratio of volume by out-of-market CRA }\end{array}$ & .87 & .81 & .70 & .63 & .74 \\
\hline $\begin{array}{l}\text { reporters to volume by all in-market } \\
\text { institutions } \ldots \ldots \ldots \ldots \ldots \ldots \ldots \ldots \ldots \ldots \ldots \ldots\end{array}$ & .14 & .11 & .17 & .24 & 16 \\
\hline Ratio of volume by out-of-market CRA & & & & & \\
\hline reporters to volume by all institutions ${ }^{2}$ & .13 & .10 & .14 & .19 & .14 \\
\hline Excluding credit card banks $\ldots \ldots \ldots \ldots \ldots$ & .10 & .09 & .14 & .18 & .13 \\
\hline
\end{tabular}

Note. See general note to table 4.

1. Covers loans reported by CRA reporters and estimated loans by nonreporters.

out-of-market CRA reporters is somewhat larger in rural markets than in urban markets. Out-of-market CRA reporters account, overall, for 14 percent of the average dollar volume of small business lending in rural markets (third memo item), compared with 8 percent in urban markets (table 3 ). In the smallest rural markets, out-of-market CRA reporters account for an average of 19 percent of the volume of small business loans.

\section{Importance of Out-of-Market CRA Lenders}

An overall judgment as to whether out-of-market CRA lenders are an important competitive force within local banking markets (that is, are able to affect prices and services) is difficult to make and is a matter for additional research. The data indicate that in both urban and rural markets, the average number of out-of-market CRA reporters, relative to the average number of in-market institutions, is not trivial. In urban markets, out-of-market CRA lenders constitute 54 percent of all institutions that extend small business loans, in rural markets, 63 percent. Out-ofmarket CRA lenders also account for a sizable proportion of small business loans, by number, in local banking markets - an average of 31 percent in urban markets and 17 percent in rural markets-though these percentages fall sharply when credit card banks are excluded.

Out-of-market reporters seem to be less significant when small business lending is measured by dollar volume. In urban markets, they account for only 8 percent of small business loan volume, including loans by credit card banks; in rural markets, they
2. Denominator is volume of loans made by all in-market institutions plus volume made by out-of-market CRA reporters.

appear to be more important, accounting, on average, for about 14 percent of small business lending volume.

\section{SMALL BUSINESS LOAN CONCENTRATION}

Indexes of concentration, as noted earlier, are a key component of the competitive analyses of bank mergers conducted by the bank regulatory agencies and the Department of Justice (see box on concentration and the Herfindahl-Hirschman index). The new CRA data enable the construction of concentration indexes based on small business loan originations and the comparison of these indexes with more traditional indexes based on bank deposits. An analysis of these concentration measures provides evidence that is relevant to the competitive analysis of bank mergers.

\section{Urban Markets}

HHIs for urban markets were calculated in four ways. Two of the measures were based on deposits, and two were based on small business loan originations. One of the deposits-based HHIs was calculated using the deposits of commercial banking institutions onlythe measure often used by the Department of Justice to approximate concentration in small business loan markets. The other deposits-based measure, "standard deposits," was calculated using commercial bank deposits plus 50 percent of thrift institution (savings association) deposits-the measure typically used by the Federal Reserve. A portion of thrift institution deposits are included in the latter measure because these institutions generally provide competi- 
tion for a portion of the "cluster" of banking products, namely banking services for households; in many cases they provide little or no competition for small business services.

One of the loan-based HHIs was calculated using the dollar volume of loans originated by only in-market institutions, including CRA reporters and nonreporters. The other was calculated using the dollar volume of loans originated by in-market institutions plus out-of-market CRA reporters. A comparison of the two indexes provides a measure of the average effect of out-of-market lenders on small business loan concentration.

In all but one instance, concentration rises as urban market population declines (table 7). This is a common finding and reflects the tendency of smaller markets to have fewer banking firms, each holding a relatively large individual market share. And, as discussed in the box on concentration and the HHI, the mathematical properties of the HHI are such that large individual market shares have the effect of rapidly increasing the level of the HHI.

The inclusion of thrift deposits causes the average HHI to decline substantially from the level of the banks-only HHI. For example, for all urban markets, the average banks-only HHI is 1991 and the average standard-deposits HHI is 1639.

The disparity between the average banks-only and standard-deposits HHIs across all urban markets calls attention to the analytical differences between the Department of Justice and the Federal Reserve System. The Department of Justice has often used the banks-only HHI as a proxy for small business loan competition but has only occasionally included thrift institutions in its HHI calculations. The Federal Reserve, in contrast, typically includes 50 percent of thrift deposits in its calculations of concentration. Thus, for any bank merger proposal, these two antitrust authorities can have different initial perceptions of market concentration.
The data also show that the loan-based HHIs are smaller than the deposits-based HHIs for the largest urban markets but increase rapidly as population decreases and exceed the deposits-based HHIs for the smaller urban markets. Significantly, the inclusion of originations by out-of-market CRA reporters has a pronounced effect in lowering the level of loan concentration for urban markets. For all urban markets, for instance, the average loan-based HHI falls from 2130 to 1816 when out-of-market lenders are included. This finding further supports the notion that out-of-market lenders may influence concentration and competition in urban banking markets. Their importance in reducing loan concentration, moreover, appears to increase as market population decreases. Comparable declines occur for all but the largest size category of urban markets.

\section{Rural Markets}

Because very high HHI values are typical for markets with fewer than four competitors, the HHIs for rural markets were calculated in two ways-for markets with one or more institutions and for those with four or more institutions (table 8). The findings are similar to those for urban markets: Higher levels of the HHI, both deposits-based and loan-based, are associated with progressively smaller markets; the effect of including out-of-market CRA lenders in the loanbased HHIs is pronounced; and as the population of the market decreases, the deconcentrating effect of out-of-market lenders appears to increase.

\section{Effects of Data Choice on Measures of Market Concentration}

In general, the proportion of urban markets that are highly concentrated (HHI above 1800) or very highly

7. Average $\mathrm{HHI}$ in urban markets, by basis for calculation and size of market, 1996

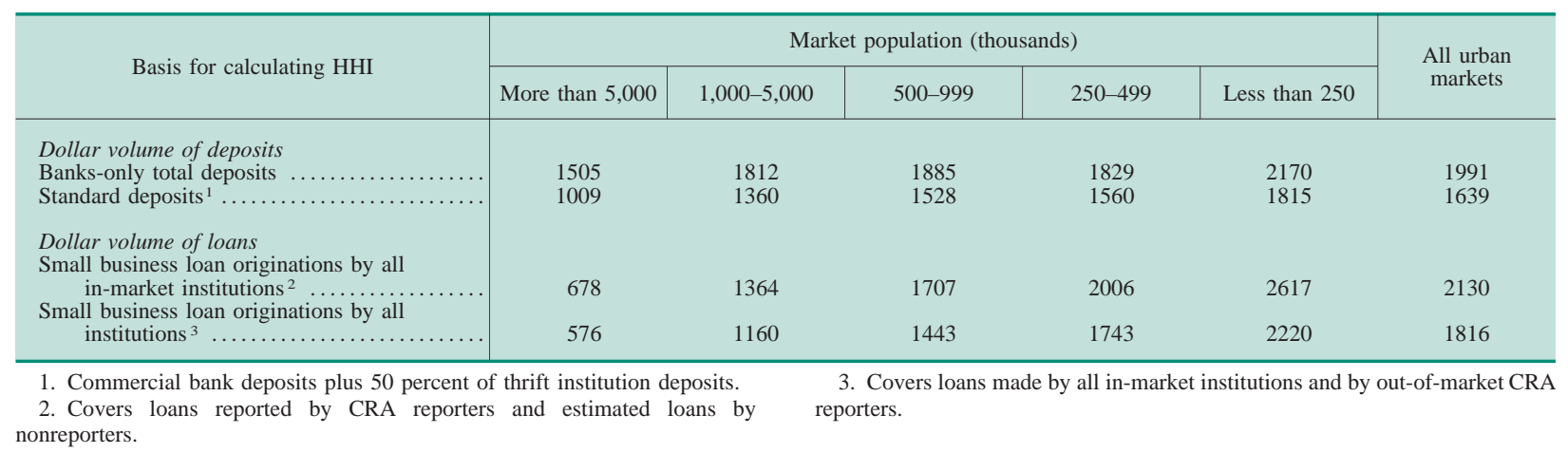


8. Average HHI in rural markets, by basis for calculation, number of institutions in market, and size of market, 1996

\begin{tabular}{|c|c|c|c|c|c|}
\hline \multirow{2}{*}{$\begin{array}{l}\text { Basis for calculating HHI and } \\
\text { number of institutions in market }\end{array}$} & \multicolumn{4}{|c|}{ Market population (thousands) } & \multirow{2}{*}{$\begin{array}{l}\text { All rura } \\
\text { markets }\end{array}$} \\
\hline & More than 100 & $50-100$ & $25-49$ & Less than 25 & \\
\hline \multicolumn{6}{|l|}{ Dollar volume of deposits } \\
\hline \multicolumn{6}{|l|}{ Banks-only total deposits } \\
\hline One or more institutions & 2681 & 2556 & 2888 & 4784 & 4145 \\
\hline Four or more institutions & 2660 & 2530 & 2810 & 3172 & 2955 \\
\hline \multicolumn{6}{|l|}{ Standard deposits } \\
\hline One or more institutions .. & 1968 & 2146 & 2532 & 4526 & 3844 \\
\hline Four or more institutions & 1964 & 2113 & 2452 & 2867 & 2611 \\
\hline \multicolumn{6}{|l|}{ Dollar volume of loans } \\
\hline \multicolumn{6}{|l|}{$\begin{array}{l}\text { Small business loan originations by all } \\
\text { in-market institutions }\end{array}$} \\
\hline One or more institutions...$\ldots \ldots \ldots$ & 2580 & 3269 & 4425 & 6768 & 5812 \\
\hline Four or more institutions $\ldots \ldots \ldots \ldots$ & 2580 & 3245 & 4306 & 5563 & 4756 \\
\hline \multicolumn{6}{|l|}{$\begin{array}{l}\text { Small business loan originations by all } \\
\text { institutions }\end{array}$} \\
\hline One or more institutions $\ldots \ldots \ldots \ldots$ & 2059 & 2581 & 3109 & 4453 & 3955 \\
\hline Four or more institutions ... & 2059 & 2575 & 3023 & 3734 & 3305 \\
\hline
\end{tabular}

Note. See notes to table 7.

concentrated (HHI above 2200) can vary considerably depending on the choice of data used in the HHI calculation (table 9). In rural markets, however, the choice of data matters much less because the vast majority of rural markets are highly concentrated regardless of which of the four HHI measures is considered.

In both urban and rural markets, the standarddeposits HHI generates the largest proportion of unconcentrated or moderately concentrated markets (HHI of 1800 or less). For example, 64 percent of urban markets are so rated when HHIs are calculated using bank deposits plus 50 percent of thrift deposits, compared with only 46 percent when only bank deposits are used.

Urban markets are most concentrated when calculations are based on the small business lending of in-market lenders. For example, 60 percent of all urban markets are highly or very highly concentrated when HHIs are based on the dollar volume of small business loans originated by in-market institutions. The proportion falls to 43 percent when small business loans originated by out-of-market CRA report- ers are included. The same general relationship exists for rural markets, but the vast majority of these markets are very highly concentrated regardless of the way the $\mathrm{HHI}$ is measured.

\section{CONCLUSIONS AND LIMITATIONS}

Overall, the new CRA data provide support for the view that out-of-market lenders may be an important source of small business lending in many markets. The data indicate that out-of-market lenders are relatively numerous throughout both urban and rural banking markets, and in most markets they outnumber in-market institutions. Also, in many markets, out-of-market lenders appear to account for a sizable proportion of small business loans, by number, although their share of such loans declines steadily with market population. Notably, if the loans of credit card banks are excluded, the average market share of loans provided by out-of-market lenders declines to half or less, suggesting that credit card loans account for a large proportion of the lending activity of outof-market reporters.

9. Percentage distribution of urban and rural markets by degree of concentration, 1996

\begin{tabular}{|c|c|c|c|c|c|c|c|c|}
\hline \multirow[t]{2}{*}{ Basis for calculating HHI } & \multicolumn{2}{|c|}{$\begin{array}{l}\text { Unconcentrated } \\
\text { (HHI 0-999) }\end{array}$} & \multicolumn{2}{|c|}{$\begin{array}{c}\text { Moderately } \\
\text { concentrated } \\
\text { (HHI 1000-1800) }\end{array}$} & \multicolumn{2}{|c|}{$\begin{array}{c}\text { Highly } \\
\text { concentrated } \\
\text { (HHI 1801-2200) }\end{array}$} & \multicolumn{2}{|c|}{$\begin{array}{c}\text { Very highly } \\
\text { concentrated } \\
\text { (HHI above 2200) }\end{array}$} \\
\hline & Urban & Rural & Urban & Rural & Urban & Rural & Urban & Rural \\
\hline \multicolumn{9}{|l|}{ Dollar volume of deposits } \\
\hline Banks-only total deposits & 4.2 & .2 & 42.2 & 6.6 & 23.3 & 8.7 & 30.4 & 84.6 \\
\hline Standard deposits ......... & 10.2 & .3 & 54.0 & 11.0 & 20.8 & 11.2 & 15.0 & 77.5 \\
\hline \multicolumn{9}{|l|}{ Dollar volume of loans } \\
\hline \multirow{2}{*}{$\begin{array}{l}\text { Small business loan originations } \\
\text { by all in-market institutions } \\
\text { Small business loan originations } \\
\text { by all institutions } . . . \ldots \ldots . .\end{array}$} & 4.8 & 8.5 & 35.1 & .7 & 21.1 & 2.2 & 39.0 & 88.6 \\
\hline & 13.4 & $*$ & 43.5 & 5.9 & 14.4 & 9.7 & 28.8 & 84.3 \\
\hline
\end{tabular}

Note. Distributions may not sum to 100 because of rounding. See notes to ${ }^{*}$ Less than 0.05 percent. table 7. 
The lending activity of out-of-market CRA reporters seems least significant when the dollar volume of loans extended by such firms is considered. In urban markets, these firms account, on average, for about 8 percent of the dollar volume of small business lending (6 percent if credit card banks are excluded). In rural markets, their share is higher (14 percent across all rural markets), suggesting that out-ofmarket small business lenders may have a greater influence on competition in rural markets than in urban markets.

The competitive role played by out-of-market lenders (as gauged by their presence, number of loans, and dollar lending volume) is, however, quite variable across individual markets. Thus, the competitive impact of proposed mergers must be assessed on a market-by-market basis. An important complement to the analysis reported here would be research to determine whether out-of-market lenders influence loan rates and whether they extend credit to a broad base of business borrowers within local markets.

Indexes of concentration based on the new CRA data suggest that concentration for small business loans is generally higher than concentration for deposits, particularly in rural markets. However, HHI levels can vary widely depending on the data underlying the index. On average, concentration is lowest when HHIs are calculated using "standard deposits"- commercial bank deposits plus 50 percent of thrift deposits - and highest when calculated using the small business loan originations of only in-market lenders.

Finally, it should be noted that the 1996 CRA data used in this study are the first of this sort to be collected, and that data for later years could yield different results. Also, in this study the small business lending activity of nonreporting in-market institutions, although believed to be only a small proportion of overall lending activity in most markets, had to be estimated. The findings also do not account for the lending activity of out-of-market firms that are not CRA reporters. Although nonreporters are smaller institutions and are less likely to make loans in markets in which they do not have offices, the inclusion of loans by these firms would probably have a further moderating effect on loan-based HHIs. These limitations notwithstanding, the new CRA data provide a potentially valuable source of new information that is likely to be helpful in the competitive analysis of bank mergers. 